MARTA KASPROWICZ

Instytut Filozofii UMK

\title{
Tożsamość - kryzys czy rozwój?
}

Spostrzegł jak gdyby poszczególne wydarzenia zależały bardziej jedne od drugich niż od niego samego i że to właśnie go określa. Powstał świat samych właściwości bez człowieka, świat przeżyć, bez tego, który je przeżywa. Rozkład antropocentrycznej postawy, która tak długo uznawała człowieka za punkt centralny kosmosu, wreszcie doszedł do naszego „ja”. Osobowość wkrótce przestanie być czymś więcej niż tylko wyimaginowanym punktem spotkań dla wszystkiego co bezosobowe

R O B E R T M S I L

B ohaterem dzieła Roberta Musila Człowiek bez właściwości jest Urlich osobnik pozornie pozbawiony uczuć, czujący oddzielenie od każdej istoty ludzkiej, studiujący ludzi, uczący się tego, jak być człowiekiem, odczuwający nieustanny i ciągły rozkład osobowości. Jest on wolny od pozornie nierozerwalnych więzów: pokrewieństwa, religijnych, światopoglądowych; pozbawiony de facto stałych stycznych ze światem, z ludźmi; jak i większości punktów oparcia w społeczeństwie. Urlich nie znajduje w sobie żadnych trwałych, wrodzonych bądź nabytych właściwości. W świecie ulegającym 
272 
274 
276 
fanami Husserla, nie możemy dokonać redukcji fenomenologicznej, jak chciał filozof, i pozbyć się swych przedsądów. Jest to możliwe tylko wtedy, gdy pozbędziemy się iluzji "Ja" i dojrzymy, że istnieje w nas zmiana, zmienność, niejednorodność. Zjawiska te przebiegają niezwykle powoli, stąd być może to wrażenie stałości

Taką „miękką" ${ }^{20}$ osobowością, o której tu mówimy, odznaczają się przede wszystkim ludzie poszukujący, podważający tzw. oczywistości. Poznajmy dla przykładu choć trzech z nich.

\section{Metafizyczny rewolucjonista}

[Mózg - M. K.] widzi masę myśli ze wszelkimi towarzyszącymi im przypadłościami i dostrzega wielość punktów widzenia, jakie mógłby przyjąć, i kształtów, w które mógłby je ubrać, ogromny zestaw wszelkich pomysłów, a każdy, jak mu się zdaje, pilniejszy, a przy tym budzący większe wątpliwości - także nigdy nie wystarczyłoby do ich przetłumaczenia i wyrażenia wszelkich zdań wtrąconych, jakie tylko zna składnia...

Antonin Artaud jest nauczycielem takich osobowości jak Jerzy Grotowski czy Michel Foucault. Podobnie jak Georges Bataille związany był z ruchem wczesnego surrealizmu. Od surrealizmu odszedł, ponieważ uznał, że Breton i jego towarzysze za bardzo kochają życie, by się czemuś poświecić w zupełności, zatem kroczył własną ścieżką. „Znajdował się on w większym konflikcie z życiem niż my wszyscy. Opętany był przez rodzaj wściekłości, która nie przepuściła, by tak rzec, żadnej ludzkiej instytucji" - wspomina André Breton ${ }^{21}$. Nie oszczędzał się, a towarzysze mieli wrażenie, że zużywa on tyle sił, iż nie będzie sposobu, by móc je na powrót odbudować - był antyspołeczny i pogardzał życiem, zatem nie mógł współpracować z innymi, i nikt nie zdołałby z nim współpracować. Pamiętajmy o tym, że surrealiści

\footnotetext{
Zainteresowanych odsyłam do utworu Tomasza Plata Być i nie być, gdzie wprowadzone jest przez autora pojęcie miękkiej osobowości.

21 L. Kolankiewicz, Święty Artaud, Gdańsk 2001, s. 53.
} 
280 
282

282 
Psycholog Louis A. Sass w tekście „Objawy negatywne”, zdrowy rozsądek $i$ kulturowe odkotwiczenie $w$ wieku nowoczesnym ${ }^{37}$ daje wyraźnie do zrozumienia, iż schizofrenia, która cechowała Artauda, a szczególnie jej objawy podstawowe, tzw. negatywne, są zjawiskami niezwykle paralelnymi z tymi charakteryzującymi osobowości postmodernistyczne (o których pisał m.in.: Zygmunt Bauman), jak i te żyjące $\mathrm{w}$ świecie po ponowoczesnym. Pewien niezakorzeniony sposób poruszania się we współczesnym świecie, szczególny rodzaj nadrefleksyjności i utrata naturalnej oczywistości (zdrowy rozsądek), tj. dotychczasowych punktów oparcia (chodzi o rosnącą świadomość np.: ciała, uczestnictwa w grze kulturowej) jak się okazuje ma swój udział w tym, co do tej pory uważano za objawy kliniczne choroby psychicznej.

\title{
Nieostre życie bohatera literackiego
}

\author{
Jak fotogeniczne musi być moje ja.
}

J E R Z Y K O S I ŃS K I

W jednym życiu można grać wiele ról. Każdy z nas inscenizuje swe życie, ale dzieje się to $w$ dużej mierze nieświadomie. Świadomym inscenizowaniem swego życia zajmował się Jerzy Nikodem Lewinkopf, znany jako Jerzy Kosiński lub Joseph Novak. Już posiadanie trzech zestawów „przedstawiania się" daje nam przedsmak tego, jak potrafił manipulować swą osobą.

Urodził się 14 czerwca 1933 roku w Łodzi, zmarł w 1991 w Nowym Jorku. Studiował u prof. Józefa Chałasińskiego na Uniwersytecie Łódzkim, gdzie uzyskał dyplom na wydziale nauk politycznych i historii. Po studiach został asystentem w PAN-ie. W 1957 roku wyjechał na stypendium do Stanów Zjednoczonych, gdzie pozostał na stałe. W 1965 roku otrzymał amerykańskie obywatelstwo. Był stypendystą Guggenheima (1967), Forda (1968) i American Academy (1970), oraz absolwentem Columbia University. Wykładał na uniwersytetach Yale, Princeton, Davenport i Wesleyan. Był laureatem prestiżowej National Book Award (1969), otrzymał wyróżnienia National Institute of Arts and Letters (1970), Le Prix du Meilleur Livre Etranger (1966) i inne. Został uhonorowany także przez Amerykańską Akademię Sztuki i Literatury. W 1973 wybrano go prezesem amerykańskiego Pen Clubu, którą to funkcję sprawował przez dwie kadencje. Był prezesem Oksfordzkiego Instytutu Studiów Polsko-Żydowskich, fotografikiem, aktorem i scenarzystą fil-

L. A. Sass, „Objawy negatywne”, zdrowy rozsadek i kulturowe odkotwiczenie w wieku nowoczesnym, [w:] Schizofrenia, kultura i subiektywność - na krawędzi doświadczenia, red. R. J. Barrett, J. H. Jenkins, przeł. J. Bobrzyński, K. Gdowska, Kraków 2005, s. 343-371. 
mowym $^{38}$. Nie sposób nie być pod wrażeniem wielości jego zainteresowań, zajęć i pracy, jaką wykonał, by uczynić swe życie interesującym i wartym przeżycia.

Książki Kosińskiego były i są tłumaczone na wiele języków świata. Najważniejszą, bo otwierającą mu drogę do kariery i najwybitniejszą jednocześnie powieścią Jerzego Kosińskiego, jest napisany w 1965 roku Malowany ptak. Narosło wiele wątpliwości nie tylko co do treści powieści, ale również autorstwa. Wraz z Kosińskim, dobrze mówiącym, ale słabo piszącym po angielsku, nad tekstem pracowało kilku, mniej albo bardziej świadomych swej roli redaktorów ${ }^{39}$. Redakcja, do której Kosiński wysłał tekst, uznała, że nie nadaje się on do druku ze względu na treść, jak i formę. Gdy w końcu udało się wydać powieść, podzieliła ona krytykę na tych, którzy utrzymywali, że jest to wyjątkowe pod względem językowym, wybitne dzieło literatury anglojęzycznej oraz wstrząsający dokument zasługujący na uwagę, i na tych, którzy twierdzili, iż Malowany ptak to „produkt umysłu ogarniętego obsesją sadomasochistycznej przemocy, mnożącego okropieństwa bez próby zbudowania szerszej wizji" ${ }^{40}$. Efektem kolektywnego tłumaczenia i niejasnej do końca roli samego Kosińskiego w tworzeniu wersji ostatecznej, jest dzieło utkane $\mathrm{z}$ autentycznych przeżyć autora, podanych $\mathrm{w}$ formie surrealistycznej paraboli przedstawiającej sytuację jednostki, która nie potrafi normalnie funkcjonować $\mathrm{w}$ grupie, i jest $\mathrm{z}$ niej wykluczana $\mathrm{z}$ powodu odmienności. Można zatem powiedzieć że udało się stworzyć tu szerszą wizję ludzkiego losu. Bohaterem jest mały Jurek. Dziecko w sposób naturalny jest wyobcowane ze świata (dorosłych), dlatego ukazana w utworze II wojna światowa ma dla Jurka wymiar apokaliptyczny. Nieważne, czy dramat rozgrywa się w Polsce, czy gdziekolwiek indziej; nieistotne, czy chłopiec przemierzający symboliczny, straszny las jest Żydem, Cyganem, czy tylko ich przypomina - istotna jest jego sytuacja odmieńca, ,pomalowanego ptaka zadziobanego przez stado, którym kieruje nienawiść do koloru oraz instynkt przynależności do szarego stada" ${ }^{41}$. Nawet wojna, demoralizująca wieśniaków żyjących na obrzeżach cywilizacji europejskiej i równie skutecznie demoralizująca dziecko, nabiera wymowy ponadczasowej i uniwersalnej, jako najpełniejsze ucieleśnienie zła

\footnotetext{
Zob. J. P. Sloan, Jerzy Kosiński. Biografia, przeł. E. Kulik-Bielińska, Warszawa 1997, s. 77-90. Kosiński zagrał w filmie „Being There” (1979) u boku Shirley Maclaine i Petera Sellersa, do którego napisał scenariusz na podstawie własnej powieści pt. Wystarczy być, w „Reds” (1981) zagrał u boku Diane Keaton, Jacka Nicholsona, Gene'a Hacmana, Warrena Beatty, w „The Statue of Liberty” (1985) u boku Milosa Formana, Arthura Millera i Jeremy'ego Irosa, oraz w „Religion” (1989) u boku Sandry Bullock.

Zob. tamże, s. 180-185.

Tamże, s. 193.

Tamże, s. 145.
} 
przyrodzonego naturze ludzkiej. Z tego punktu widzenia zarzuty o antypolskość powieści wydają się absurdalne i świadczą, o nieodczytaniu jej przekazu i potraktowaniu w sposób naiwny jako dokumentu.

Jerzego Kosińskiego można nazwać mitomanem, gdyż mit w jego życiu odegrał rolę fundamentalną. Mit rodzi się tam, gdzie następuje nagromadzenie sensów, znaczeń o różnorodnym ładunku, ale też tam, gdzie ich brakuje, gdzie występuje kryzys wartości. W jego życiu wiele było nadmiaru (fantazji), jak i braku (tożsamości). Z wielkim talentem i fantazją wymyślał swoje życie, tworzył swoje liczne fikcyjne życiorysy. Niemal do końca życia pozostał wierny zasadzie obudowywania swojej osoby opowieściami nieprawdziwymi, które częstokroć raz wypowiedziane, stawały się „faktami”. Czynił to zarówno w kontaktach z innymi ludźmi, kiedy to kreował swój niepowtarzalny intelektualny i seksualny wizerunek, jak też przede wszystkim w literaturze. Bujnemu rozkwitowi mitotwórstwa Kosińskiego sprzyjał jego wyjazd do Stanów Zjednoczonych, gdzie w nowym, „nieznającym” go środowisku bez wielkiego ryzyka demaskacji mógł nie tylko snuć swoje opowieści i autobiografie, ale też wymyślić od nowa całą swoją przeszłość. Do dziś - o czym najlepiej wiedzą zagubieni biografowie i zdezorientowani czytelnicy poszukujący prawdy o pisarzu - istnieje nie tylko bardzo wiele białych plam w jego życiorysie, ale też niepewność towarzysząca pisaniu o nim: bo jak odcedzić prawdę od tego, co mówił o sobie i co mówili o nim inni? Warto pamiętać, że on sam nie widział tego w sposób dialektyczny, dualny, więc zalecam, by recepcja jego dzieł i biografii nie opierała się na rozterkach w kwestii: prawdy i fałszu; to jak chcieć oglądać filmy Davida Lyncha z nadzieją na rozwiązanie zagadki.

U progu dojrzałego życia i twórczości Jerzego Kosińskiego legł niezwykle ważny mit założycielski. Można powiedzieć, tylko nieznacznie ryzykując przesadę, że powieść Tadeusza Dołęgi-Mostowicza Kariera Nikodema Dyzmy (1932) stanowiła przełom w życiu Kosińskiego, a postawa tytułowego bohatera uświadomiła mu zarazem cel, do którego chciałby w życiu dotrzeć i środki, którymi mógłby to osiągnąć. Zrozumiał też, że to właśnie Ameryka jest miejscem, gdzie będzie mógł wyśnić swój sen o karierze jak z bajki. Jeśli więc książka jest w stanie wpłynąć na ludzkie życie, to ta lektura młodości z całą pewnością zmieniła życie Kosińskiego - odtąd będzie on kształtował je tak, aby powieliło wzorzec literacki, a do siebie przykładał będzie miarę literackiego bohatera ${ }^{42}$. Literatura wcielona $\mathrm{w}$ prawdziwe życie okazała się determinantem oszałamiającego sukcesu: barwnego, zmiennego, niepowtarzalnego, nieprawdopodobnego, pełnego niedomówień i kontrowersji życia

Tamże, s. 61-62. 
gwiazdy, ale i losu przeklętego. Otóż mit Dyzmy, który zrodził amerykańskiego pisarza, doprowadził go niespełna dwadzieścia lat później na skraj przepaści. Ponadto na fali ataków przypuszczonych przez dziennikarzy na znajdującego się u szczytu sławy Kosińskiego, trzecią jego powieść Wystarczy być oskarżono o plagiat... Kariery Nikodema Dyzmy. Jak to bywa często w biografii Kosińskiego, nie sposób rozstrzygnąć jednoznacznie, czy popełnił ów plagiat, czy był to jedynie zwyczajny dla jego twórczości przypadek autobiografizacji, w której życiorys autora-bohatera do złudzenia przypomina życie bohatera literackiego. Plagiat czy inspiracja, a może nieświadoma, naturalna konsekwencja obrania sobie Dyzmy za mistrza i wzór? Kosiński był zarówno twórcą i wytworem swoich mitów. Jak wyjaśnia to jego biograf: „,jest to jeden $\mathrm{z}$ tych przypadków, które pokazują, jak wymyślnie przeplatają się ze sobą sztuka i życie. [...], sztuka i życie naśladują siebie nawzajem" ${ }^{43}$.

Zawikłana tożsamość Kosińskiego: Polak, Żyd, „wilk stepowy”, „malowany ptak”, „pisarz-skandalista”, jest bardzo złożonym problem poszukiwania i porzucania przez pisarza kolejnej tożsamości. Stąd też poważny problem z jego tożsamością mają także jego biografowie, ale i polscy historycy literatury, którzy wciąż nie zdecydowali, czy jego nazwisko wypada umieszczać w syntezach i omówieniach polskiej - co nie zawsze oznacza polskojęzycznej - literatury powojennej. Co dziwne, Amerykanie nie mają tego problemu: regularnie używają przy okazji postaci Kosińskiego sformułowania: „pisarz amerykański”. Brak Kosińskiego w polskiej świadomości literaturoznawczej jest nie tylko niezrozumiały, ale wręcz upokarzający w jakiś sposób nas samych. Polacy mają ciągły problem z przeszłością, jakiś histeryczny, niezbywalny resentyment do całego świata i sentyment do własnej pamięci historycznej.

W nocy 3 maja 1991 roku Jerzy Kosiński zadzwonił do swojej najbliższej w tamtym czasie przyjaciółki - Urszuli Dudziak. Na pożegnanie miała ponoć usłyszeć od niego: zadzwonię do ciebie, jak się obudzę. Z dużą dawką alkoholu zmieszał dużą dawkę środków nasennych, rozebrał się, wszedł do wanny, a dla pewności założył na głowę torbę foliową. Rano żona Kiki znalazła go martwego. Przyczyny i okoliczności jego śmierci do dziś budzą kontrowersje i spory. Samobójstwo było jednym z tematów literackich przewijających się w twórczości Kosińskiego ${ }^{44}$.

Tamże, s 62.

P. Sarzyński, Leksykon samobójców, Warszawa 2002, s. 182, 183. 


\section{Człowiek - nieczłowiek}

By patrzeć, potrzebujesz przestrzeni, a myśl tę przestrzeń tworzy. Przestrzeń jako wymiar istnieje tylko jako wytwór myśli. Umysł teoretyzuje na temat stworzonej przez siebie przestrzeni, tworząc „continuum czasoprzestrzenne". Czas jest niezależną jakością, strukturą, nie ma potrzeby, by istniała ciągłość pomiędzy nim a przestrzenią

U. G .

Mechanistyczno-organiczny sposób bycia Uppaluri Gopala Krishnamurtiego uzmysławia nam praktykę bycia bez protez mistycznych, umiejętność bycia „nago” wobec świata. Będziemy go tu nazywać - jak to się przyjęło - U. G. Można powiedzieć, że istniał na kształt maszyny, zwierzęcia czy też rośliny, w każdym razie był kimś/czymś pozbawionym określenia. Nie przywiązywał się do ludzi, rzeczy ani świata.

„Moje nauki, jeśli tego słowa chcecie użyć, nie mają praw autorskich. Możecie je dowolnie reprodukować, rozprowadzać, interpretować, przekręcać, możecie robić z nimi co wam się żywnie podoba, możecie nawet podpisać się pod nimi i przypisać sobie ich autorstwo bez czyjejkolwiek zgody. Macie na to moje przyzwolenie" ${ }^{45}$. Tak głosi napis na jednej z pierwszych stron książki, której bohaterem jest U. G., ale który bynajmniej nie uważa się za jej autora. Powstała ona, jak i pozostałe, bez jego bezpośredniego udziału, z powodu Innych. Nieustannie nagabywali go jacyś obcy ludzie, zainteresowani jego osobą, zadający mnóstwo pytań i oczekujący na jego odpowiedzi; spisywali namiętnie jego słowa i wydawali w formie wywiadów. Słów, które wypowiadał, nie uważał za swoje, tak traktował wszystkie rzeczy na tym świecie, zupełnie inaczej niż ma to miejsce w przypadku większości ludzi; jak wyjaśnia: „lękamy się przekraczać przyswojonych nawyków i ustalonych norm. Tzw. inteligencja jest według niego akceptacją ograniczeń i jest to powód naszego cierpienia i bólu. Nasze działania sprowadzają się do tego, że

45 Umyst jest mitem. Niepokojące rozmowy z czlowiekiem zwanym U.G., red. T. Newland, przeł. W. Ostrowski, I. i T. Rosca, A. Sobota, Wrocław 1994, s. 4. 
jedne ograniczają drugie. Każde nasze działania wyznaczają te, które będą następne"

U. G. wzrastał w rodzinie bramińskiej i szykowany był na kapłana, ale zmysł sceptyczny nie pozwolił mu na bierne przyjmowanie tradycji. Przyswoił cały proces buddyjskiej pracy nad myślami i uczuciami, by po prostu się go pozbyć, ale kosztowało go to utratę tożsamości, niemalże utratę życia. Nie wiedział dokładnie, czy przeżyje proces usuwania iluzji, ale wiedział, że w iluzji żyć nie chce. Jego intelektualne podróże odsyłały go do kolejnych nauczycieli. Nieustannie szukał odpowiedzi na pytanie, co to jest oświecenie i czy może je osiągnąć? Wszyscy nauczyciele rozprawiali o tym zjawisku, ale żaden $\mathrm{z}$ nich nie potrafił mu tego pokazać, dać. W którymś momencie swego życia, słuchając jednego z wykładów buddyjskich, uzmysłowił sobie, że on jest „oświecony”, ale nie w sposób duchowy, tylko fizyczny. Wolność, o której mówili mistycy, była po prostu znanym mu od dawna naturalnym sposobem działania organizmu. (Wolność może być synonimem rozpadu struktury Ja, pozbawieniem kontroli racjonalnego rozumu). Oświeceniem okazało się odrzucenie wszystkich pytań, które nieustannie zadawał. Dopóki je miał, dopóty szukał odpowiedzi i zrozumiał, że te poszukiwania dławiły naturalny „stan bycia” organizmu, powodowały, że się męczył, a w konsekwencji go „psuły”. „Nie istnieje żadne duchowe czy psychiczne oświecenie, ponieważ nie ma czegoś takiego jak duch i psyche. Umysł to tylko układ obwodowy elektromagnetyczny. Byłem skończonym głupcem, żeby szukać całe życie czegoś, czego nie ma. Moje poszukiwania dobiegły kresu" ${ }^{47}$.

W jednej chwili wszystkie pytania zniknęły, został uwolniony od różnicującego sposobu myślenia. Wyjaśnia to Terry Newland: „pewien ładunek energii poprzez jeden ze zmysłów został wprowadzony do jego mózgu i pozostawiony własnemu losowi. Taki pozostawiony swobodnej wibracji ładunek, pozbawiony kontroli, niewyjaśniony, niezinterpretowany i niespożytkowany przez różnicującą i mającą, by tak rzec, prawo pierwokupu strukturę myślenia, może okazać się rzeczą bardzo niebezpieczną, stanowiąc zarzewie wewnętrznej anarchii" ". Ładunek ów, „nietknięty” przez myślenie i czas, nie znajdując drogi ujścia, powoduje napięcie molekularne, które doprowadziło do eksplozji, rozpadu systemu myślenia, a wraz z nim do rozpadu niezależnego, indywidualnego odrębnego Ja. Ustało działanie zasady przyczynowoskutkowej i osiągnięty został kres przeciwieństw. „Kataklizm przeniknął komórki i sięgnął aż do poziomu chromosomów, mając charakter czysto fi- 
zjologiczny, nie zaś psychologiczny" ${ }^{49}$. U. G. był wolny od związków kulturowych, przestał identyfikować się z mężczyzną, braminem, Hindusem, podróżnikiem, mówcą, człowiekiem cywilizowanym, prawym i sprawiedliwym etc. Zobaczył ubranego samoświadomego ssaka, używającego narzędzi do tego, żeby radzić sobie z życiem; wolnego od oczekiwań i roszczeń. Dotarł do domu i położył się. Odczuwał skurcze w całym ciele, szczególnie w okolicach czoła, skroni, potylicy. Pojawiły się obrzmienia w okolicach gruczołów przysadki, szyszynki, grasicy i krtani. Powieki znieruchomiały. „Pojawiło się coś w rodzaju spalania czy jonizacji komórek, podnosząc temperaturę ciała do niewiarygodnej wysokości i wyrzucając rodzaj popiołu, który wyraźnie można było zaobserwować na ciele" ${ }^{, 50}$. Podobnie jak zawiesza się komputer, tak U. G. zamierał kilka razy, osuwając się w stan bliski śmierci, w którym niemal ustawała akcja serca, temperatura obniżała się do minimum, a całe ciało było sztywne jak w agonii, po czym ponownie „zaskakiwało”: temperatura się podnosiła, puls ożywiał i pojawiały się ruchy ciała. Ta fizyczna transgresja trwała latami: przez rok była bardzo intensywna, a potem przebiegała już prawie niezauważalnie.

Wszystko to, co zaszło, jest, zdaniem U. G., spowodowane zniknięciem wielkiego zarządcy, jakim jest Ja, które zostało zdemaskowane, okazując się tylko indywidualną, nabytą strukturą psyche. Nagle zabrakło psychicznego koordynatora kontrolującego, analizującego i segregującego zmysłowe doznania. Zdarzenia utraciły wszelkie powiązania ze sobą i stały się chaotyczne. Zmysły działały naturalnie, a treści nabyte zapadły się, ale nie znikły, dlatego mogły być nadal przywoływane, gdy zachodziła taka konieczność, np.: wiedza na temat tego, do czego służą przedmioty codziennego użytku i co to w ogóle jest „przedmiot codziennego użytku”; U. G. wiedział, czym jest miłość i nienawiść, ale już nie potrafił ich odczuwać. Została tylko „sucha” wiedza (jak pliki zapisane na dysku) bez zdolności jej przeżywania. Przeżywane było tylko to, co naturalne - na przykład dotyk, lecz pozbawiony już interpretacji (czułość, zaczepka itp.). Pole widzenia przybrało formę panoramiczną, rozszerzyło się do $360^{\circ}$, podczas gdy obserwator zniknął zupełnie, a obrazy zdawały się przenikać bezpośrednio ciało i głowę. U. G. został pozbawiony punktów odniesienia i wszystko miało na niego wpływ, stał się niewiarygodnie wrażliwy biologicznie, odczuwał jak przenika go powietrze, a nawet jak przepływa krew w żyłach. „Naturalny przepływ energii, nie blokowany i nie rozpraszany przez wartościujące myślenia, biegnie teraz bezpośrednio z rdzenia kręgowego poprzez mózg i uwalnia się w okolicach

${ }^{49}$ Tamże.

50 Tamże. 
szczytu głowy" ${ }^{\text {51 }}$. Po roku tych doświadczeń nie był w stanie mówić. Gdy już się przyzwyczaił do ciągłych zmian w swoim organizmie, powoli zaczął uczyć się wysławiać swe myśli. Ale mówił niechętnie, bo cóż można powiedzieć po czymś takim? Ciało zostało uwolnione od przeszłości, od pytań i zaczęło funkcjonować bez ustawicznego, problematycznego myślenia. Wszelkie roszczenia i pragnienia, za wyjątkiem podstawowych potrzeb życiowych, uległy wymazaniu. $Z$ tego powodu U. G. nie proponuje żadnych wykładów na temat tego, jak się znaleźć w takim miejscu, w jakim on się znalazł, również dlatego, że każde doświadczenie jest niepowtarzalne (doświadczenie Jezusa jest doświadczeniem Jezusa, doświadczenie Buddy jest doświadczeniem Buddy, nikt nie może pójść ich drogą, musi iść własną, dlatego stawianie im pomników, zrzeszanie wyznawców jest, zdaniem U. G., paranoją). Pytany o własne doświadczenie odpowiadał, nie mając jednak złudzeń, że komuś to pomoże.

\section{Kryzys, zmiana, przełom, rozwój...}

Wróćmy na koniec do rozważań na temat tego, jak powstał problem $\mathrm{z}$ tożsamością. Dawno, dawno temu... nie było przeszłości i przyszłości, w naszym rozumieniu tego słowa, Ja nie było mocno wyodrębnione ze świata, odróżnione od innych. Przeszłość była święta, a przyszłość miała być powrotem do przeszłości (do prapoczątku), a więc była przeszłością, którą otwierało się w trakcie rytuałów, rządzących się czasem sakralnym (występują tu trzy fazy wyszczególnione przez A. van Gennepa: wyłączenia, zawieszenia, włączenia). „Wieczny początek” odtwarzany był cyklicznie, w każdym rytuale, a trzeba pamiętać, że świat pierwotny cały składał się z rytuałów, niczego nie robiono „ot tak sobie", wszystko było ograniczone konkretnym mechanizmem zachowania, od którego nie było odstępstwa. W trakcie rytuału dochodziło do spotkania z przodkami, z którymi wszelako obcowało się i na co dzień: duchy przodków towarzyszyły na każdym kroku. Zatem Ja tkwiło jednocześnie w przeszłości, jak i w teraźniejszości, i nie wybiegało w przyszłość. Potem w procesie rozwoju myśli zachodniej, ale również wschodniej, „myśl ta wynalazła przeciwieństwo czasu - «teraz», «wieczne teraz» [...]. Jednakże teraźniejszość istnieje tylko jako idea. Chwila, w której próbujesz patrzeć na teraźniejszość, już przeniosła się w królestwo przeszłości", ${ }^{52}$. Przeszłość jest

Tamże, s. 25.

Tamże, s. 74. Platońsko-kartezjańska idea duszy uwięzionej w ciele zostaje tu przez U. G. Krishnamurtiego, podobnie jak u Michela Foucaulta przekształcona na rzecz ciała ujarzmionego przez kajdany duchowe, zatem „idea” nie jest niczym innym, jak tylko fatamorganą, świat abstrakcyjnych bytów zostaje tu zdegradowany do poziomu naszych snów o świecie. 
głównym motorem naszego działania i rozwoju. To, co przeżyliśmy, ma dla nas znaczenie i wpływa na to, kim jesteśmy. Nie ma przyszłości, nie ma teraźniejszości, jest tylko przeszłość. Jeślibyśmy spróbowali być świadomi teraźniejszości, zdawać sobie sprawą z „teraz”: momentu gdy myślimy, czujemy, jemy, oddychamy, chodzimy, zaczęlibyśmy „potykać się” o własne nogi, myśli i uczucia. „Oddychanie jest automatyczne i jeśli spróbujesz być świadomym każdego oddechu, oszalejesz. Nie wymyślaj dróg dochodzenia do oświecenia, stopni medytacji. Sprawy mają się wystarczająco źle i bez tego" ${ }^{53}$.

Jednak nasz rozwój wymaga takiego „kryzysu”, mutacji, aberracji rzeczywistości: nowych jakości. Ruch w grze kulturowej wymaga tworzenia się nowatorskich metafor, nowych odczytań natury, do których dochodzi dzięki sytuacjom kryzysowym. Niepowodzenia i rozczarowania na drodze ku poszukiwaniu sensu życia, choćby były tylko naszą imaginacją, mobilizują nas do szukania innych, prekursorskich sposobów, by osiągnąć ten nieuchwytny cel. Zapewne pojawienie się sytuacji kryzysowej nie byłoby dla nas tak nieprzyjemne, gdybyśmy uświadomili sobie, że wszystko jest niepewne, nietrwałe i przygodne, i że mniemamy inaczej tylko $\mathrm{z}$ racji wolno upływającego czasu... jednak czy wtedy nadal byśmy próbowali? Nasze życie rozgrywa się w kryzysach, a kryzysy tożsamościowe skutkują ponownym odkryciem nicości ludzkich spraw, a to przeraża. Przerażającym jest też fakt, że świadomość jest elastyczna, że można ją poszerzać, naginać do własnych celów i forsować własne racje, dekonstruować jej nadruki mentalne.

Mózg i psychika nie ma centrum. „Tak jak synapsy nerwowe znajdują się w stanie ciągłej interakcji ze sobą, stale tworząc odmienną konfigurację ładunków elektrycznych, tak samo nasze przekonania i pragnienia są w stanie ciągłej interakcji, redystrybuując wartości prawdziwościowe między zdaniami. Tak jak mózg nie jest czymś co «ma» takie synapsy, lecz jest po prostu ich nagromadzeniem, tak samo Ja nie jest czymś, co «ma» przekonania i pragnienia, lecz jest po prostu siatką takich przekonań i pragnień, ${ }^{54}$.

„Myślę, więc jestem” - to stwierdzenie wcale nie jest tak oczywiste, jak mogłoby się wydawać. Podstawy naszej tożsamości, czyli umysł lub też jaźń czy dusza, nie są pewnikami, lecz założeniami, zakładamy, że je mamy, że są. Istnienie Ja przyjmowane jest na wiarę, sprawdzić jego istnienia nie sposób (przy tego typu próbach obiekt się wymyka). Współczesne koncepcje filozoficzne o charakterze antyesencjalistycznym, antypsychiatrycznym,

Tamże, s. 34

A. Szahaj, Ironia i miłość. Neopragmatyzm Richarda Rorty'ego w kontekście sporu o postmodernizm, Wrocław 2002, s. 51. 


\section{Kryzys w polityce}

kontruktywistycznym sugerują, że jeśli porzucimy to naiwne myślenie, to okaże się, że mamy dużo większy wpływ na to, kim możemy być, kim chcielibyśmy się stać. Być może nie da się odwrócić pewnych procesów socjalizacyjnych i inkulturacyjnych, ale można wykorzystać najbliższe otoczenie do tego, by się zmieniać, rozwijać i z większą łatwością pokonywać progi, granice, kryzysy. 


\section{Abstract}

This article considers an issue of identity. It is an attempt to answer the question whether the crisis of identity is not just a breakdown of anthropocentric attitude that assumes homogeneousness, permanence and invariability of identity. And if so, why cannot crises be treated as development of internal possibilities that in this odd and 'crisisian' way try to come to the surface.

Mental problems may be the symptoms of the necessity of change in one's life and if the individuals cannot deal with them and change their lives for better, they experience positive disintegration - as it can be called in Kazimierz Dąbrowski's terms. The moment of crisis can be compared to 'suspension stage', distinguished by Victor Turner who based it on the 'ritual of passage', as Arnold van Gennep called it. In primitive cultures, entering the adults' world meant ending the period of childhood and separating from social environment for certain time. Thus, a 'new' man was supposed to play new role - in this case, a role of an adult. Postmodern reality may be characterised by terms such as: fluency, plurality and casualness. There is no need of excluding and including, therefore individuals acting within such frames need to be ambiguous to act well. The have to be deprived of any stabile role just like a character of Robert Musil's Man without propriety, who studies how to be a man, spends his whole life on learning and creating his personality. These are experienced creators - artists and thinkers - who are able to teach the individuals how their personality may be softened. 